\title{
Biological and ecological factors related to trace element levels in harbour porpoises (Phocoena phocoena) from European waters
}

\author{
V. Lahaye ${ }^{a,{ }^{*}}$, P. Bustamante ${ }^{a}$, R.J. Law ${ }^{b}$, J.A. Learmonth ${ }^{c}$, M.B. Santos ${ }^{c, d}$, J.P. Boon ${ }^{e}$, \\ E. Rogan ${ }^{f}$, W. Dabin ${ }^{g}$, M.J. Addink ${ }^{h}$, A. López ${ }^{i}$, A.F. Zuur ${ }^{j}$, G.J. Pierce ${ }^{c}$, F. Caurant $^{a}$
}

\footnotetext{
${ }^{a}$ Centre de Recherche sur les Ecosystèmes Littoraux Anthropisés, UMR 6217 CNRS-IFREMER-Université de La Rochelle, 22 Av. Michel Crépeau, 17042 La Rochelle Cedex, France

${ }^{\mathrm{b}}$ The Centre for Environment, Fisheries and Aquaculture Science, Burnham Laboratory, Remembrance Avenue, Burnham-on-Crouch, Essex CM0 8HA

${ }^{\mathrm{c}}$ School of Biological Sciences, University of Aberdeen, Tillydrone Avenue, Aberdeen, ABZ4 2TZ, UK

d Instituto Español de Oceanografía, Centro Oceanográfico de Vigo, P.O. Box 1552, 36200, Vigo, Spain

e Royal Netherlands Institute for Sea Research, P.O. Box 59, 1790 AB Den Burg, Texel, the Netherlands

${ }^{f}$ Aquaculture Development Centre, Department of Zoology, Ecology and Plant Science, University College, Lee Maltings, Prospect Row, Cork, Ireland

${ }^{9}$ Centre de Recherche sur les Mammifères Marins, Institut du Littoral et de l'Environnement, Port des Minimes, Av. du Lazaret, 17000 La Rochelle, France

hationaal Natuurhistorisch Museum, P.O. Box 9517, 2300 RA Leiden, The Netherlands

'CEMMA, Apdo. 15, 36380 Gondomar, Pontevedra, Spain

${ }^{j}$ Highland Statistics, 6 Laverock Road, Newburgh, Aberdeenshire, AB41 6FN, UK.
}

"Corresponding author. Tel./Fax.: +33 (0)5 46500294.

E-mail address: vlahaye@univ-Ir.fr (V. Lahaye).

\begin{abstract}
:
Selected trace elements ( $\mathrm{Cd}, \mathrm{Cu}, \mathrm{Hg}, \mathrm{Se}, \mathrm{Zn})$ were measured in the kidneys and the liver of 104 harbour porpoises (Phocoena phocoena) stranded along the coasts of France, Galicia (Spain), Ireland, Scotland (UK), and the Netherlands. Generally, relatively low concentrations of toxic elements were encountered in the tissues of European porpoises, except for two individuals, which displayed high hepatic Hg concentrations. Also, elevated Cd levels obtained in Scottish porpoises could be related to their feeding preferences and this result suggests an increase of the proportion of cephalopods in their diet with latitude. Moreover, significant geographical differences were seen in hepatic Zn concentrations; the elevated Zn concentrations displayed by porpoises from the Netherlands may relate their poor health status. Variation in metal concentrations within porpoises from the North Sea is likely to reflect a long-term segregation between animals from northern (Scotland) and southern areas (the Netherlands), making trace elements powerful ecological tracers.
\end{abstract}

Keywords: heavy metals, mercury, cadmium, zinc, marine mammals, age, diet, multivariate analysis, tracers 


\section{Introduction}

Harbour porpoises (Phocoena phocoena) are one of the most common cetaceans in European waters (Hammond et al., 2002). Through the last century, declines in harbour porpoise populations have occurred in some northern European areas, particularly in the Baltic Sea (Benke et al., 1998; Koschinski, 2002), the southern North Sea and the English Channel (Klinowska, 1991; DOE, 1995). Several potential threats such as fishery by-catch, depletion of food resources, marine traffic and exposure to contaminants may have been responsible for the decline of these stocks (Evans, 1991; IWC, 1994; Koschinski, 2002).

Consequently, the harbour porpoise has been categorised as vulnerable by the IUCN (The World Conservation Union) and it also constitutes a prioritised species in conservation and management for the UK (UK Biodiversity Plan Action; DOE, 1995), North Sea and adjacent areas (ASCOBANS, Agreement on the Conservation of Small Cetaceans of the Baltic and North Seas).

Harbour porpoises are relatively long-lived upper-level predators, which mainly inhabit coastal temperate areas (Read, 1999). Although these areas constitute productive systems in terms of providing nursery areas and habitats, they are also the repository for toxic agents and hazardous materials from industrial, agricultural and urban sources. These numerous sources contribute to sewage wastes, organic compound and heavy metal environmental enrichment. The question of whether environmental pollution is changing the dynamics of marine mammal populations remains yet as unresolved. Indeed, bioaccumulation and long-term exposure to contaminants could be expected to pose a threat to the health and viability of these upper-level predators, especially for those living in industrial coastal areas, as it is the case for harbour porpoises in the north-eastern Atlantic (Aguilar and Borrell, 1995).

To date, experimental studies have shown that exposure to persistent organic contaminants could cause reproductive failure (e.g. Reijnders, 1986), immunosuppression (e.g. Ross et al., 1996), and diseases (e.g. De Guise et al., 1995) in some marine mammal species. As well, some studies have correlated high levels of mercury $(\mathrm{Hg})$ and zinc $(\mathrm{Zn})$ with the health status in free-living harbour porpoises (Siebert et al., 1999; Bennett et al., 2001; Das et al., 2004a; Strand et al., 2005; Kannan et al., 2006). However, causal connections to outbreak of diseases and increased mortality are likely to be complex, which make it difficult to evaluate the extent to which pollutants may contribute to adverse health effects in situ (Busbee et al., 1999). In particular, one additional aspect to consider regarding exposure to metals is that marine mammals have developed efficient detoxification capacities to support high levels of some toxic metals like $\mathrm{Hg}$ and cadmium (Cd) (see reviews by Cuvin-Aralar and Furness (1991) and Das et al. (2000)).

Concerning $\mathrm{Hg}$, the demethylation of organic $\mathrm{Hg}$ in the liver leads to its co-precipitation with selenium (Se). Resulting non-toxic granules of tiemannite ( $\mathrm{HgSe})$ are stored in the liver, making it the ultimate organ of retention of $\mathrm{Hg}$ (Koeman et al., 1973; Martoja and Berry, 1980; Nigro and Leonzio, 1996). In the kidneys, $\mathrm{Hg}$ would rather be linked to proteins rich in sulphur (Chen et al., 1974; Neve and Therond, 1991), which could constitute a second route for $\mathrm{Hg}$ detoxification. Like $\mathrm{Hg}$ in the liver, $\mathrm{Cd}$ levels can also be particularly elevated in the kidneys of marine mammals (Wagemann and Muir, 1984; Dietz et al., 1998). In fact, potential toxic effects of $\mathrm{Cd}$ are mitigated by the binding to metallothioneins (MTs) in the liver and the kidneys (Klaassen and Liu, 1997; Teigen et al., 1999). MT is a low molecular weight protein, which also plays a key role in the homeostasis of $\mathrm{Zn}$ and copper (Cu) (Webb and Cain, 1982).

Although trace element levels in harbour porpoises are now well-documented for some northern European areas, i.e. the North Sea, the Baltic Sea and the Celtic shelf (Law et al., 1991, 1992; Siebert et al., 1999; Bennett et al., 2001; Das et al., 2004a,b; Strand et al., 2005; Ciesielski et al., 2006), an overview of metal accumulation in porpoises is still required over a larger geographical scale in order to determine whether metallic pollution could constitute a particular threat for the populations that are generally considered as "at risk" (i.e. from northern areas) compared to more "healthy" ones (i.e. from southern areas). Therefore, by providing trace element data for some non-documented southern areas (i.e. the Atlantic coasts of France and Spain), as well as contemporaneous data for parts of northern Europe, this study aims at identifying geographical variations of trace element bioaccumulation $(\mathrm{Cd}$, $\mathrm{Cu}, \mathrm{Hg}, \mathrm{Se}, \mathrm{Zn}$ ) in the liver and the kidneys of harbour porpoises stranded along European coasts, and at identifying the main factors influencing concentrations (including diet and persistent organic 
pollutant levels - POPs). The influence of diet on metal concentrations was investigated through fatty acid measurements since they constitute efficient integrated indicators of diet (e.g. Iverson et al., 1997, 2004; Bradshaw et al., 2003). Detoxification efficiency in these populations is also considered through the measurements of the essential elements that are linked to the neutralisation of $\mathrm{Hg}$ (i.e. Se) and linked to $\mathrm{Cd}$ detoxification (i.e. $\mathrm{Cu}$ and $\mathrm{Zn}$ ), through MT induction. In addition, we investigated health status of some animals but these data were used at the interpretation stage only since direction of causality in relationships between high contaminant levels and disease mortality is not wellestablished (see Jepson et al., 2005).

\section{Material and methods}

\section{Sampling and data collection}

Between 1997 and 2003, 104 stranded harbour porpoises were collected along the coasts of Scotland (UK, $n=36$ ), France $(n=24)$, Ireland $(n=22)$, Netherlands $(n=19)$, and Galicia (Spain, $n=3)$ (see Fig. 1). All carcasses were in good post-mortem condition, varying from a very fresh state to slightly decomposed. During each necropsy, individual characteristics of each animal were recorded and some tissues were sampled for further analyses, following the protocol from Kuiken and Hartmann (1991). Field information included date and location of stranding, gender and blubber thickness. Teeth were sampled in order to determine the age, blubber was used for fatty acid analyses and POPs measurements, and lastly, the kidneys and liver were dedicated for trace element analyses.

Temporal variation in trace element levels was investigated both at annual and seasonal (quarterly) scales. Quarters were defined as Q1, January to March, Q2, April to June, Q3, July to September, and Q4, October to December. In addition, an index of nutritive condition was determined following blubber thickness, i.e. B1, <10 mm, B2, 10-15mm, B3, 15-20mm, B4, 20-25mm, and B5, $>25 \mathrm{~mm}$. Note that blubber thickness may vary seasonally in cetaceans (Elsner, 1999; Lockyer et al., 2003; Learmonth, 2006), but since we include season as an explanatory variable, any marginal effect of blubber thickness is arguably be related to condition. Where possible, necropsy included assessment of disease status and cause of death, with porpoises that died from trauma (i.e. by-catch, predation) being separated from those that presented significant pathologies (mainly pneumonia and lung parasitism).

Age was determined following the recommendations of Perrin and Myrick (1980). Briefly, this procedure consists of counting Growth Layer Groups (GLGs) from teeth sections, assuming that one GLG equals one year. Moreover, after lipid extraction of the inner blubber layer from a complete blubber core, 31 fatty acids were analysed by gas chromatography with flame ionisation detection (GC-FID). Concerning POPs analyses, organochlorines (18 PCB congeners, p,p-DDE and HCB) were determined by gas chromatography with electron capture detection (GC-ECD) whereas brominated flame retardants (5 PBDE congeners) were determined using gas chromatography mass spectrometry with negative chemical ionisation (GC-NCl/MS). More details about these methods and detailed results are presented in Pierce et al. (2004), Zegers et al. (2005) and Learmonth (2006).

\section{Trace element analyses}

Tissues (kidneys, liver) dedicated to trace element analyses were stored in plastic bags at $-20^{\circ} \mathrm{C}$ until being processed in the laboratory. Then, all equipment used in the sample processing was cleaned, and subsequently decontaminated for $24 \mathrm{~h}$ in a solution composed of $35 \mathrm{ml} \mathrm{HNO}_{3}(65 \%)$ and $50 \mathrm{ml} \mathrm{HCl}$ (36\%) for $1 \mathrm{~L}$ of Milli-Ro quality water. Fresh samples were freeze-dried and ground to powder. The mean ratio between dry weight (d.wt.) and wet weight (w.wt.) was 0.29 for liver and 0.23 for kidney. Each sample was then treated in duplicate.

For total $\mathrm{Hg}$ measurements, aliquots ranging from 0.5 to $2 \mathrm{mg}$ of dried-material were analysed in an Advanced Mercury Analyser spectrophotometer (Altec AMA 254). Hg determination in the AMA 254 involved evaporation of $\mathrm{Hg}$ by progressive heating to $800{ }^{\circ} \mathrm{C}$ under oxygen atmosphere for $3 \mathrm{~min}$, and subsequent amalgamation on a gold net. The net was then heated to liberate the collected $\mathrm{Hg}$, which was measured by Atomic Absorption Spectrophotometry (AAS). For other trace elements analyses 
(i.e. $\mathrm{Cd}, \mathrm{Cu}$, Se and $\mathrm{Zn}$ ), 2 aliquots of approximately $200 \mathrm{mg}$ of each homogenised dry sample were digested with $3.5 \mathrm{ml}$ of $65 \% \mathrm{HNO} 3$ at $60{ }^{\circ} \mathrm{C}$ for 3 days. The digested contents were then diluted to $10 \mathrm{ml}$ in milli-Q quality water. Then $\mathrm{Cd}, \mathrm{Cu}$ and $\mathrm{Zn}$ contents were assayed using a flame (Varian 250 Plus) AAS with deuterium background correction whereas Se and some low Cd contents were analysed with graphite furnace AAS (Hitachi Z-5000) with Zeeman background correction.

Quality controls were made using standard reference materials from National Research Council of Canada, i.e. dogfish liver (DOLT-2 and DOLT-3), dogfish muscle (DORM-2), and lobster hepatopancreas (TORT-2). These reference materials were treated and analysed under the same conditions as the samples. Results were in good agreement with the certified values (see Table 1). In addition, the laboratory participates in intercalibration exercises organised by the International Atomic Energy Agency (cf. Coquery et al., 1999). During the last exercise, our laboratory was classified in group 1, indicating the good quality of results for all analysed elements (Azemard et al., 2006). Detection limits ( $\mu$ g.g- 1 d.wt.) were 0.004 for $\mathrm{Cd}, 0.5$ for $\mathrm{Cu}, 3$ for $\mathrm{Zn}, 0.8$ for Se, and 0.005 for $\mathrm{Hg}$. Metal concentrations in porpoise tissues were expressed as $\mu \mathrm{g} . \mathrm{g}-1 \mathrm{w} . \mathrm{wt}$.

As in previous studies on marine mammals (e.g. Falconer et al., 1983; Wagemann and Muir, 1984; Mackey et al., 1995), we found that concentrations of $\mathrm{Cd}$ were relatively low in the liver of some harbour porpoises. We report only renal $\mathrm{Cd}$ concentrations in this paper because far more porpoises were analysed for $\mathrm{Cd}$ in this tissue than in the liver. As well, Se was measured only in the liver since this tissue constitutes the ultimate site of $\mathrm{Hg}$ detoxification (Koeman et al., 1973; Martoja and Berry, 1980).

\section{Data treatment}

All concentrations below the detection limit were replaced with "dummy values" that were half of the detection limit in order to allow further statistical comparisons (Gibbons and Coleman, 2001). The sampled porpoises from Ireland included two mother-foetus pairs, allowing us to make some preliminary observations about relationships between metal concentrations in mother and foetus tissues.

Because trace element concentrations may depend on numerous biological and ecological factors (e.g. Aguilar et al., 1999), redundancy analysis (RDA) was used to relate trace element data to putative explanatory factors. This analysis was carried out on normalised data, excluding data for the two foetuses, using the software package Brodgar (www.brodgar.com). The explanatory variables selected were location and date (year, quarter) of stranding, gender, blubber thickness classes, age, fatty acid profiles and POPs concentrations. Because RDA is based on regression, the number of explanatory variables had to be smaller than the number of samples. A selection of variables was also required for the fatty acids and POPs explanatory variables. Hence, principal component analysis (PCA) was applied to the POPs data and to the fatty acid data and, in each case, the scores of the first two PC axes were used as explanatory variables in the RDA. Nominal data were coded as a set of dummy variables, each taking the value 0 or 1 . Finally, Spearman's rank correlations were calculated in order to determine relationships between trace elements. In addition, we focussed on the $\mathrm{Hg}$ detoxification process through the calculation of $\mathrm{Hg}$ :Se molar ratio. This ratio was calculated as: $\mathrm{Hg}: \mathrm{Se}$ $=\left(\mathrm{Hg}\left(\mu \mathrm{g} \cdot \mathrm{g}^{-1}\right.\right.$ w.wt. $) / \mathrm{Se}\left(\mu \mathrm{g} \cdot \mathrm{g}^{-1}\right.$ w.wt. $\left.)\right) \times\left(78.96\left(\mathrm{~g} \cdot \mathrm{mol}^{-1}\right) / 200.59\left(\mathrm{~g} \cdot \mathrm{mol}^{-1}\right)\right)$, where $200.59 \mathrm{~g} \cdot \mathrm{mol}^{-1}$ and $78.96 \mathrm{~g} \cdot \mathrm{mol}^{-1}$ are the atomic mass of $\mathrm{Hg}$ and Se, respectively.

\section{Results}

\section{Trace element levels}

Two foetus/mother pairs were collected along the Irish coast. As trace element concentrations in foetuses were excluded in the further statistical analyses, Table 2 gives the concentrations exhibited by the two foetus/mother pairs, as well as mean concentrations of the overall data set (without foetuses, $n=102$ ).

Concentrations of $\mathrm{Cd}, \mathrm{Hg}$, and Se were particularly low in foetuses $(<1 \mu \mathrm{g} \cdot \mathrm{g}-1 \mathrm{w}$ w.w.) compared to mothers, and especially in the case of hepatic $\mathrm{Hg}$ and Se. Indeed, a 6 year-old female collected along 
the Irish Sea coast exhibited 140 and 65 fold higher concentrations of hepatic $\mathrm{Hg}$ and Se, respectively, than its foetus. Conversely, hepatic $\mathrm{Cu}$ concentrations were about 5 times higher in foetuses than their mothers. No such differences between foetuses and mothers were detected for $\mathrm{Cu}$ in the kidneys or for $\mathrm{Zn}$ in either liver or kidneys.

Concerning overall data (excluding foetuses), the highest coefficients of variation were encountered for $\mathrm{Cu}, \mathrm{Hg}$ and $\mathrm{Se}$ in liver, and $\mathrm{Cd}$ in kidneys (CV\% >100). For these elements, maximal concentrations were obtained in animals aged from 4 to 6 years-old, except in the case of hepatic $\mathrm{Cu}$, for which the highest concentrations was encountered in a 0.5 year-old individual. Maximal renal $\mathrm{Cd}$ and hepatic $\mathrm{Hg}$ concentrations were obtained in porpoises from the northern North Sea $(11.9 \mu \mathrm{g} . \mathrm{g}-1$ w.wt.) and Irish Sea (165 $\mu$ g.g-1 w.wt.) respectively. In addition, several maxima occurred in porpoises from Southern North Sea, i.e. for renal Hg, and hepatic $\mathrm{Cu}$, Se and $\mathrm{Zn}$.

\section{Factors influencing trace element concentrations}

Table 3 summarises results from RDA, which related trace element data to location (countries) and date (years, quarters) of stranding, gender, blubber thickness classes, age, blubber fatty acid profiles and blubber POPs concentrations. All investigated explanatory variables together explained $36.0 \%$ of the variation of trace element data, among which the first two axes respectively explained $49.5 \%$ and $15.8 \%$ of (explained) metal variability (Table 3 ). We observed close relationships between axis $1, \mathrm{Hg}$ and Se, as well as between axis 2 and $\mathrm{Cd}$ (Fig. 2a).

Hence, the most important explanatory variables were age $(p=0.005)$, and the Netherlands (i.e. the difference between samples from the Netherlands and those from elsewhere, $p=0.005)$. The second PCA axis score summarising fatty acid profiles had a weakly significant effect $(p=0.04)$, as did season (quarter $1, p=0.04$, quarter $3, p=0.045$ ). Age was well-correlated to axis 1 (i.e. to $\mathrm{Hg}$ and $\mathrm{Se}$ ) and to a lesser extent to axis 2 (i.e. to $\mathrm{Cd}$ ) (Table 3, Fig. 2a). Renal Cd concentrations were also clearly linked to the fatty acid profile (PCA axis 2) (Table 3, Fig. 2a and c). Individual plots showed that Scottish animals were those with the highest Cd levels (cf Fig. 2a and 3). Note that the "Netherlands" variable was equally correlated to both axes 1, 2, and 5 (Table 3). Examination of biplots highlighted that porpoises from the Netherlands displayed higher $\mathrm{Zn}$ concentrations in their liver than animals from other countries (Fig. 2a and b).

The seasonal variation in hepatic $\mathrm{Cu}$ and renal $\mathrm{Hg}$ concentrations may be of minor importance in relation to the overall variability of trace element data, since effects of the dummy variables representing quarters 1 and 3 were not correlated to the first two axes of the RDA (Table 3). Note also that POPs concentrations in blubber were not related to trace element levels in the kidneys and the liver (Table 3).

\section{Relationships between trace elements}

Table 4 presents Spearman correlation values $\left(R_{S}\right)$. Hepatic Se was closely and positively correlated to hepatic and renal $\mathrm{Hg}\left(R_{S}=0.909\right.$ and 0.889 , respectively). Fig. 4 illustrates geographical variation in the relationship between $\mathrm{Hg}$ and $\mathrm{Se}$ in the liver. Generally, $\mathrm{Hg}$ :Se molar ratios ranged from 0.16 to 1.27, with only seven animals from four areas (northern and southern North Sea, north-western Scotland, Irish Sea) displaying a molar excess of $\mathrm{Hg}$. Most animals (i.e. 73\%) exhibited a $\mathrm{Hg}$ :Se molar ratio lower than 0.8 .

\section{Discussion}

\section{Cadmium}

Relatively low $\mathrm{Cd}$ concentrations were encountered in the kidneys of harbour porpoises from the western coasts of Europe. Indeed, mean renal Cd level of the overall sample $(n=102)$ was only 1.32 $\pm 1.81 \mu \mathrm{g} \cdot \mathrm{g}^{-1}$ w.wt. (Table 2). Aguilar \& Borrell (1995) firstly hypothesized that such low levels could be due to the physiological peculiarity of the harbour porpoise, or reflect stable low levels of $\mathrm{Cd}$ in their 
environment. In fact, $\mathrm{Cd}$ concentrations in the tissues of marine mammals are generally considered to be diet-related (Aguilar et al., 1999). Feeding on cephalopods is probably a major source of Cd for small cetaceans both because of the high Cd levels in these prey and because $\mathrm{Cd}$ is present mainly in bioavailable forms in their tissues (Bustamante et al., 1998; 2002).

As a result, close relationships were previously found to occur between renal Cd concentrations and muscular stable isotope ratio of nitrogen in porpoises from European waters (Das et al., 2004a). Here, RDA showed a correlation between renal $\mathrm{Cd}$ concentrations and one of the synthetic variables summarising fatty acid profiles (Fig. 2ac, Table 3), which would be expected to reflect diet. Note that Scottish porpoises would be those with the highest Cd levels (Figs. 2ac, 3) and that the maximal Cd concentration obtained during this study $\left(11.9 \mu \mathrm{g} \cdot \mathrm{g}^{-1} \mathrm{w}\right.$.wt.) was found in a 4 year-old individual from this area (Table 2). Such a high Cd concentration nevertheless remains far below those displayed by harbour porpoises from higher latitudes (i.e. Greenland and Iceland; Table 5), in which renal Cd levels often reach the $50 \mu \mathrm{g} \cdot \mathrm{g}^{-1}$ w.wt. threshold suspected to produce toxic effects in humans (Elinder \& Järup, 1996). The much higher Cd levels commonly encountered in harbour porpoises from arctic areas occur despite the fact that the concentration of $\mathrm{Cd}$ in seawater is about the same in temperate and arctic waters (Mølenberg \& Jensen, 1980; Elinder, 1985; Asmund, pers. comm. fide PalludanMüller et al., 1993). In fact, Cd levels are well-known to be elevated in arctic sediments and organisms (e.g; MacDonald \& Sprague 1988; AMAP, 1998; Dietz et al., 1998; Zauke et al. 1999), and especially in cephalopods (Bustamante et al., 1998). The squid biomass occurring in stomach contents is much higher in porpoises from Greenland (up to 37\%; Heide-Jørgensen \& Lockyer, 1999) than in European ones (up to 7.3\%; Pierce et al., 2004), which could explain the higher renal Cd levels obtained in Greenland animals compared to European animals. Within Europe, Scottish porpoises consume a larger proportion of cephalopods than porpoises from the other studied countries (Pierce et al., 2004; Santos et al., 2004; Spitz et al., 2006). Such a differential consumption of cephalopods might also induce higher $\mathrm{Cd}$ levels in the tissues of Scottish porpoises as demonstrated elsewhere for common dolphins (Lahaye et al., 2005). Consequently, the overall south to north increase of Cd concentrations in the kidneys of harbour porpoises from north-eastern Atlantic (see Table 5) strongly suggests a diet modification at the population scale, which would be characterised by an increase of cephalopod consumption with latitude, maybe related to feeding over deeper waters.

Regarding relationships between metals, the essential elements $\mathrm{Cu}$ and $\mathrm{Zn}$ are commonly related to $\mathrm{Cd}$ (Das et al., 2000), which would suggest induction of MTs and possible competition or increase in metal binding-sites (Klaassen \& Liu, 1997; Wagemann et al., 1988; Teigen et al., 1999). Here, neither the $\mathrm{Cd}-\mathrm{Cu}$ nor $\mathrm{Cd}-\mathrm{Zn}$ relationships were significant (Table 4). Hence, the low $\mathrm{Cd}$ concentrations to which porpoises may be exposed in European waters are probably not sufficient to induce $\mathrm{Cu}$ or/and $\mathrm{Zn}$ ion displacement from MTs, and consequently leading to co-accumulation with $\mathrm{Cd}$. Such results could easily be confirmed through MT measurements in the kidneys of porpoises.

Hepatic $\mathrm{Cu}$ concentrations were higher in foetuses than their mothers (Table 2), presumably due to an important transplacental transfer of this metal during pregnancy (e.g. Underwood, 1977; Law, 1996; Wagemann et al., 1988; Yang et al., 2004). Elevated Cu concentrations in offspring could be due to either bioaccumulation of $\mathrm{Cu}$ during pregnancy coupled with low excretion rates in foetus or a specific biochemical requirement for development (Wagemann et al., 1988). In other words, foetuses could have only limited $\mathrm{Cu}$ excretion via the bile or elevated MTs in the liver to store essential elements for growth. Conversely, the Cd levels obtained in the kidneys of foetuses were extremely low (Table 2), which is common in marine mammal foetus tissues (Honda \& Tatsukawa, 1981, 1983; Fujise et al., 1988; Wagemann et al., 1988; Law et al., 1992; Caurant, 1994; Yang et al., 2004; Lahaye et al., submitted). This clearly indicates a limited transfer of Cd during pregnancy (e.g. Bell, 1984).

\section{Mercury}

Mercury in porpoise's prey species occurs mainly in the organic form (e.g. Bloom, 1992; Bustamante et al., 2006), and methyl-Hg could be transferred from the mother, through the placenta, and accumulated in the foetus (Law et al., 1992). Here, Hg concentrations found in the tissues of foetuses were particularly low ( $<1 \mu \mathrm{g} \cdot \mathrm{g}^{-1}$ w.wt.), in comparison to concentrations found in their mothers (up to 140 fold higher in the mother's liver, Table 2). Although organic $\mathrm{Hg}$ was not measured during this study, the low $\mathrm{Hg}$ levels encountered in foetuses suggest that transplacental transfer from mother to foetus is not a major accumulation route for the offspring. Such a limited maternal transfer of $\mathrm{Hg}$ during pregnancy has been several times been pointed out for other cetacean species (Itano \& Kawai, 1981; 
Honda \& Tatsukawa, 1981, 1983; Fujise et al., 1988; Law et al., 1992; Caurant et al., 1993; Yang et al., 2004; Lahaye et al., submitted).

Excluding the two foetuses, the range of $\mathrm{Hg}$ concentrations found in this study was wide, especially in the liver, where concentrations varied from 0.28 to $165 \mu \mathrm{g} . \mathrm{g}^{-1} \mathrm{w}$.wt., against only 0.11 to $5.8 \mu \mathrm{g} \cdot \mathrm{g}^{-1}$ w.wt. in the kidneys. Although some porpoises from the North Sea have been reported to exhibit renal $\mathrm{Hg}$ concentrations reaching $30 \mu \mathrm{g} \cdot \mathrm{g}^{-1}$ w.wt. (Siebert et al., 1999), the low renal Hg levels obtained during this study are within the range of values reported in most studies carried out on this species over a large spatial scale (Gaskin et al., 1979; Falconer et al., 1983; Palludan-Müller et al., 1993; Teigen et al., 1993; Joiris et al., 2001; Das et al., 2003; 2004a).

Furthermore, and contrary to $\mathrm{Cd}$, a strong increase of $\mathrm{Hg}$ concentrations with age occurred in both the kidneys and the liver (Fig. 2a and Table 3), as reported in several studies on harbour porpoises and also on other marine mammals (see review by Aguilar et al., 1999). Such a strong relationships with age may partly explain the important variability of $\mathrm{Hg}$ concentrations in the liver (Table 2). The two highest concentrations (i.e. 165 and $139 \mu \mathrm{g} \cdot \mathrm{g}^{-1}$ w.wt., Table 5) were recorded in animals that were only 5 and 6 years-old, from Irish Sea and the Netherlands respectively. These two porpoises displayed $\mathrm{Hg}$ concentrations in liver that were at the bottom of the range likely to induce toxic effects in marine mammals (i.e. 100-400 $\mu \mathrm{g} \cdot \mathrm{g}^{-1}$ w.wt.; Wagemann \& Muir, 1984). Such extreme concentrations have previously been reported in the liver of harbour porpoises and other marine mammals from the Irish Sea and Dutch waters and they were attributed to anthropogenic inputs (Reijnders, 1986; Law et al., 1992; Simmonds et al., 1993; Das et al., 2004a). However, when looking at the population scale, no significant differences in $\mathrm{Hg}$ accumulation were detected among areas (Table 3, Figs. 2a and 3). Hence, excluding these two individuals from the Irish Sea and the Netherlands, Hg levels would be equivalent throughout the study area, indicating that the northern populations generally considered as "at risk" are not particularly more threatened by exposure to $\mathrm{Hg}$ than the more "safe" populations from southern areas.

Numerous studies have discussed the protective effect of Se on $\mathrm{Hg}$ toxicity and a molar ratio of 1:1 for $\mathrm{Hg}: \mathrm{Se}$ has been reported to reflect efficient $\mathrm{Hg}$ detoxification in many studies involving marine mammals (e.g. Koeman et al., 1973; Palmisano et al., 1995; Caurant et al., 1996; Dietz et al., 2000). Selenium is also an essential element that is incorporated into anti-oxidant enzyme systems, and especially glutathione peroxidase (Bondy, 1996). As pointed out by Dehn et al. (2005), a 1:1 Hg:Se molar ratio would indicate that almost all available Se is bound to $\mathrm{Hg}$. Owing to the oxy-radical scavenging involvement of Se, tissue ratios close to $1: 1$ could be also a possible indicator for compromised health (Dietz et al., 2000). Most of European porpoises from this study exhibited a $\mathrm{Hg}$ :Se ratio lower than 1:1 (Fig. 4), indicating an excess of Se compare to $\mathrm{Hg}$, and thus also its bioavailability for its other functions (e.g. with glutathione peroxidase).

Finally, among the 102 studied porpoises, only 7 displayed a molar excess of $\mathrm{Hg}$ and these individuals were all collected along the coasts of the Netherlands and Irish Sea (Fig. 4). Based upon the relationships between $\mathrm{Hg}$ and $\mathrm{Se}$ in the liver, formation of tiemmanite would occur in the liver of porpoises from European waters, except in the case of a limited number of individuals, which originated from two areas that are well-known for their anthropogenic background of chemical inputs.

\section{Zinc}

Zinc is essential to the integrity of the immune system of mammals. Law et al. (1991) hypothesized a range of liver concentrations within which $\mathrm{Zn}$ could be regulated as $20-100 \mu \mathrm{g} \cdot \mathrm{g}^{-1} \mathrm{~W}$.wt. Thirteen of the 102 porpoises sampled exhibited concentrations outside this range. Respectively, 5 and 3 individuals originated from the Netherlands and the Irish Sea, and a particularly elevated concentration $\left(288 \mu \mathrm{g} . \mathrm{g}^{-}\right.$ ${ }^{1}$ w.wt) was encountered in a 9 year-old porpoise (Table 2). Among these 13 porpoises with high Zn hepatic levels, 11 individuals had a deteriorated health status, i.e. high parasitic burden and pulmonia (Pierce et al. 2004; T. Jauniaux and M.G. Hartmann, pers. comm). Such particular high Zn levels were previously reported in the liver of harbour porpoises from the North Sea that exhibited deteriorating health condition (emaciation and bronchopneumonia) (Das et al., 2004a). This increase of $\mathrm{Zn}$ concentrations in the liver could be due to a general redistribution of this metal within the organs (muscle and blubber to liver) as a result of protein and lipid catabolism. Although emaciation was not directly evaluated in our samples, trace element concentrations were not related to blubber thickness (Table 3), suggesting that only the presence of a pathology may be associated with the observed high $\mathrm{Zn}$ hepatic levels. In humans, it is well-established that infection is associated with $\mathrm{Zn}$ redistribution, 
and in particular, that concentrations in liver rise as a result of acute-phase protein synthesis (Scott, 1985; Hambridge et al., 1986; Amdur et al., 1991). As Zn does not accumulate with age (Fig. 2a), the high $\mathrm{Zn}$ concentrations encountered in porpoises that exhibited pathological features are probably a response to infections rather than a direct cause. In addition, given that half of the Netherlands sampling was composed of animals with pathology, the higher Zn levels obtained for this area (Fig. 2a and c, Table 3) could also be related to their poor health status. Note also that particularly high POPs levels have been encountered in the blubber of Netherlands porpoises, suggesting that this compromise health status could be induced by organic pollution in this area (Pierce et al. 2004).

\section{Conclusions}

The present study confirms results from various studies on the $\mathrm{Cd}$ and $\mathrm{Hg}$ in marine mammals from Arctic and temperate regions, which indicates that animals from lower latitude display far lower $\mathrm{Cd}$ levels in their tissues and that the $\mathrm{Hg}$ levels are about the same in both areas, despite a higher anthropogenic influence in temperate waters (Palludan-Müller et al., 1993; Szefer et al., 2002; Bustamante et al., 2004; Das et al., 2004a). This is likely to reflect lower rates of Cd exposure through temperate marine food webs compare to polar and subpolar areas, for which Cd natural enrichment of food webs is well-established (MacDonald \& Sprague 1988; AMAP, 1998; Dietz et al., 1998; Zauke et al., 1999).

In general, stock structure (genetic and ecological) should be considered when considering conservation and management needs for a given species. Within European waters, both mitochondrial DNA (mtDNA) and microsatellite data suggest that harbour porpoises would constitute a single continuous population, which would be characterised by a fine scale partitioning according to latitude (Fontaine et al. submitted). Trace element concentrations are now well-known as interesting tracers to provide to provide further ecological information about a given species (e.g. Das et al., 2003, 2004a; Lahaye et al., 2005; Caurant et al., 2006). Here, some renal Cd level differences occurred among northern and southern areas of the North Sea. In addition, animals from the southern area also displayed higher $\mathrm{Zn}$ levels that those stranded northern (probably because of the poor health status displayed by Netherlands individuals). Such results indicate that a long-term ecological segregation would occur in porpoises from northern and southern areas of the North Sea. Furthermore, it has to be pointed out that some Netherlands porpoises were displaying the highest values of both hepatic $\mathrm{Hg}$ and $\mathrm{Zn}$, plus Hg:Se in the liver, but also PCBs in blubber (Pierce et al., 2004). Despite no correlations between POPs concentrations in blubber and trace elements have presently been detected, the simultaneous occurrence of particularly elevated levels of some metallic and organochlorine contaminants in Netherlands porpoises could also compromise their health status.

\section{Acknowledgements}

We are very grateful to all the participants of national stranding networks of France, Ireland, Scotland, the Netherlands and Galicia. Thanks to C. Churlaud from the Centre Commun d'Analyses from La Rochelle for technical assistance. Thanks also to RJL and colleagues from CEFAS for providing trace element data in Scottish porpoises. This work was funded by the European program BIOCET (EC: EVK3-CT-2000-00027) and through a research grant from the Conseil Régional de Poitou-Charentes to V.L. 


\section{References}

Aguilar, A., \& Borrell, A. (1995). Pollution and harbour porpoises in the Eastern North Atlantic: a review. In A. Biørge \& G.P. Donovan (Eds.), Biology of the Phoecoenids (pp. 231-242). Cambridge: International Whaling Commission.

Aguilar, A., Borrell, A., \& Pastor, T. (1999). Biological factors affecting variability of persistent pollutant levels in cetaceans. In P. Reijnders, A. Aguilar, G.P. Donovan (Eds.), Chemical pollutants and cetaceans (pp. 82-116), vol. special issue 1. UK: Journal of Cetacean Research and Management.

AMAP (Arctic Monitoring and Assessment Programme) (1998). AMAP assessment report: arctic pollution issues, Chapter 7: Heavy metals (pp. 374-453). Oslo: Arctic Monitoring and Assessment Programme.

Amdur, M.O., Doull, J., \& Klaassen, C.D. (1991). Toxicology: the Basic Science of Poisons. New York: McGraw-Hill.

Azemard, S., de Mora, S.J., Guitart, C., \& Wyse, E. (2006). World-wide intercomparison exercise for the determination of trace elements and methylmercury in tunafish flesh homogenate IAEA-436. Report n' IAEA/AL/157 IAEA/MEL/77, 98p.

Bell, J. (1984). The toxicity of cadmium in the newborn. In S. Kacew \& M.J. Reasor (Eds.), Toxicology and the newborn (pp. 201-215). Elsevier Science Publisher B.V.

Benke, H., Siebert, U., Lick, R., Bandomir B, \& Weiss, R. (1998). The current status of harbour porpoises (Phocoena phocoena) in German waters. Archive of Fisheries and Management Resources, 46, 97-123.

Bennett, P.M., Jepson, P.D., Law, R.J., Jones, B.R., Kuiken, T., Baker, J.R., Rogan, E., \& Kirkwood, J.K. (2001). Exposure to heavy metals and infectious disease mortality in harbour porpoises from England and Wales. Environmental Pollution, 112, 33-40.

Bloom, N.S. (1992). On the chemical form of mercury in edible fish and marine invertebrate tissue. Canadian Journal of Fisheries and Aquatic Sciences, 49, 1010-1016.

Bondy, S.C. (1996). Oxygen generation as a basis for neurotoxicity by metals. In L.W. Chang (Ed.), Toxicology of metals (pp. 699-706). Boca Raton: CRC Lewis Publishers.

Bradshaw, C.J.A., Hindell, M.A., Best, N.J., Phillips, K.L., Wilson, G., \& Nichols, P.D. (2003). You are what you eat: describing the foraging ecology of southern elephant seals (Mirounga leonina) using blubber fatty acids. Proceedings of the Royal Society London B, 270, 1283-1292.

Busbee, D., Tizard, I., Stott, J., \& Ferrick, D. (1999). Environmental pollutants and marine mammal health: the potential impact of hydrocarbons and halogenated hydrocarbons on immune system dysfunction. In P. Reijnders, A. Aguilar, G.P. Donovan (Eds.), Chemical pollutants and cetaceans (pp. 223-248), vol. special issue 1. UK: Journal of Cetacean Research and Management.

Bustamante, P., Caurant, F., Fowler, S.W., \& Miramand, P. (1998). Cephalopods as a vector for the transfer of cadmium to top marine predators in the north-east Atlantic Ocean. Science of the Total Environment, 220, 71-80.

Bustamante, P., Cosson, R.P., Gallien, I., Caurant, F., \& Miramand, P. (2002). Cadmium detoxification processes in the digestive gland of cephalopods in relation to accumulated cadmium concentrations. Marine Environmental Research, 53, 227-241.

Bustamante, P., Morales, C.F., Mikkelsen, B., Dam, M., \& Caurant, F. (2004). Trace element bioaccumulation in grey seals Halichoerus grypus from the Faroe Islands. Marine Ecology Progress Series, 267, 291-301. 
Bustamante, P., Lahaye, V., Durnez, C., Churlaud, C., \& Caurant, F. (2006). Total and organic Hg concentrations in cephalopods from the North East Atlantic waters: influence of geographical origin and feeding ecology. Science of the Total Environment, 369, 585-596.

Caurant, F., Amiard-Triquet, C., Amiard, J.C. (1993). Factors influencing the accumulation of metals in pilot whales (Globicephala melas) off the Faroe Islands. In: Donovan, G.P.; Lockyer, C.; Martin, A.R., eds. Biology of northern hemisphere pilot whales, Report of the International Whaling Commission, Special Issue 14, pp. 369-390.

Caurant, F. (1994). Bioaccumulation de quelques éléments traces (As, Cd, Cu, Hg, Se, Zn) chez le globicéphale noir (Globicephala melas, Delphinidé), pêché au large des îles Féroé. Thèse d'Université, Université de Nantes, 206 p.

Caurant, F., Navarro, M., \& Amiard, J.C. (1996). Mercury in pilot whales: possible limits to the detoxification process. Science of the Total Environment, 186, 95-104.

Caurant, F., Aubail, A., Lahaye, V., Van Canneyt, O., Dabin, W., Rogan, E., López, A., Addink, M., Churlaud, C., Robert, M., \& Bustamante, P. (2006). Lead contamination of small cetaceans of the European coasts - the use of stable isotopes for identifying the sources of lead exposure. Marine Environmental Research, 62, 131-148.

Chen, R.W., Wangher, P.D., \& Fang, S.C. (1974). Diversion of mercury binding in rat tissues by selenium: a possible mechanism of protection. Pharmacology Research Commission, 6, 571-579.

Ciesielski, T., Szefer, P., Bertenyi, Z., Kuklik, I., Skóra, K., Namieśnik, J., \& Fodor, P. (2006). Interspecific distribution and co-associations of chemical elements in the liver tissue of marine mammals from the Polish Economical Exclusive Zone, Baltic Sea. Environment International, 32, 524532.

Coquery, M., Carvalho, F.P., Azemard, S., \& Horvat, M. (1999). The IAEA worldwide intercomparison exercises (1990-1997): determination of trace elements in marine sediments and biological samples. Science of the Total Environment, 237-238, 501-508.

Cuvin-Aralar, A., \& Furness, R.W. (1991). Mercury and selenium interaction: a review. Ecotoxicology and Environmental Safety, 21, 348-364.

Das, K., Debacker, V., \& Bouquegneau, J.M. (2000). Metallothioneins in marine mammals. Cellular and Molecular Biology , 46, 283-294.

Das, K., Beans, C., Holsbeek, L., Mauger, G., Berrow, S.D., Rogan, E., \& Bouquegneau, J.M. (2003). Marine mammals from northeast Atlantic: relationship between their trophic status as determined by $13 \mathrm{C}$ and $15 \mathrm{~N}$ measurements and their trace metal concentrations. Marine Environmental Research, 56, 349-365.

Das, K., Siebert, U., Fontaine, M., Jauniaux, T., Holsbeek, L., \& Bouquegneau J.M. (2004a). Ecological and pathological factors related to trace metal concentrations in harbour porpoises Phocoena phocoena from the North Sea and adjacent areas. Marine Ecology Progress Series, 281, 283-295.

Das, K., Holsbeek, L., Browning, J., Siebert, U., Birkun, A. Jr., \& Bouquegneau, J.M. (2004b). Trace metal and stable isotope measurements ( $13 \mathrm{C}$ and $15 \mathrm{~N}$ ) in the harbour porpoise Phocoena phocoena relicta from the Black Sea. Environmental Pollution, 131, 197-204.

De Guise, S., Martineau, D., Beland, P., \& Fournier, M. (1995). Possible mechanisms of action of environmental contaminants on St. Lawrence beluga whales (Delphinapterus leucas). Environmental Health Perspectives, 103, 73-77.

Dehn, L.A., Sheffield, G.G., Follmann, E.H., Duffy, L.K., Thomas, D.L., Bratton, G.R., Taylor, R.J., \& O'Hara, T.M. (2005). Trace elements in tissues of phocids seals harvested in the Alaska and Canadian Arctic: influence of age and feeding ecology. Canadian Journal of Zoology, 83, 726-746. 
Dietz, R., Norgaard, J., \& Hansen, J.C. (1998). Have artic marine mammals adapted to high cadmium levels? Marine Pollution Bulletin, 36, 490-492.

Dietz, R., Riget, F., \& Born, E.W. (2000). An assessment of selenium to mercury in Greenland marine animals. Science of the Total Environment, 245, 15-24.

DOE (Department of the Environment), 1995. Biodiversity: the UK Action Plan, vols 1 and 2. HMSO.

Elinder, C.G. (1985). Cadmium: uses, occurrence and intake. In L. Friberg, C.G. Elinder, T. Kjellstrøm \& G.F. Nordberg (Eds), Cadmium and health: a toxicological and epidemiological appraisal, vol I (pp. 23-64). Boca Raton: CRC Press.

Elinder, C.G., \& Järup, L. (1996). Cd exposure and health risks: recent findings. Ambio, 25, 370-373.

Elsner, R. (1999). Living in water: solutions to physiological problems. In: Reynolds, J.E. III, Rommel, S.A. (Eds). Biology of Marine Mammals. Smithsonian Institution Press, Washington and London.

Evans, P.G.H. (1991). Whales, dolphins and porpoises: order Cetacea. In G.B. Corbet \& S. Harris (Eds.), The Handbook of British Mammals (pp. 299-350). Oxford: Blackwell Scientific Publications.

Falconer, C.R., Davies, I.M., \& Topping, G. (1983). Trace metals in the common porpoise, Phocoena phocoena. Marine Environmental Research, 8, 119-127.

Fontaine, M.C., Baird, S.J.E., Piry, S., Ray, N., Duke, S., Birkun, A.Jr., Bloch, D., Ferreira, M., Sequeira, M., Jauniaux, T., Llavona, Á., Øien, N.I., Öztürk, B., Öztürk, A., Ridoux, V., Rogan, E ., Siebert, U., Vikingsson, G.A., Bouquegneau, J.M., \& Michaux, J.R. (submitted). Rise of Oceanographic Barriers in Continuous Populations of a Cetacean: The Harbour Porpoise in Old World Waters. PloS Biology.

Fujise, Y., Honda, K., Tatsukawa, R., \& Mishima, S. (1988). Tissue distribution of heavy metals in Dall's porpoises in the Northwestern Pacific. Marine Pollution Bulletin, 19, 226-230.

Gaskin, D.E., Stonefield, K.I., Suda, P., \& Frank, R. (1979). Changes in mercury levels in harbour porpoises from the Bay of Fundy, Canada, and adjacent waters during 1969-1977. Archive of Environmental Contamination and Toxicology, 8, 733-762.

Gibbons, R.D., \& Coleman, D.E. (2001). Statistical methods for detection and quantification of environmental contamination. New York: John Wiley \& Sons, $384 \mathrm{p}$.

Hambridge, K.M., Casey, C.E., \& Krebs, N.F. (1986). Zinc. In W. Mertz (Ed.), Trace metals in human and animal nutrition, vol. 2 (pp. 53-57). Orlando: Academic Press.

Hammond, P.S, Berggren, P., Benke, H., Borchers, D.L, Collet, A., Heide-Jørgensen, M.P., Heimlich, S., Hiby, A.R., Leopold, M.F., \& Øien, N. (2002). Abundance of harbour porpoises and other cetaceans in the North Sea and adjacent waters. Journal of Applied Ecology, 39, 361-376.

Heide-Jørgensen, M.P., \& Lockyer C. (1999). The biology of harbour porpoises from West Greenland. In P.G.H. Evans \& E.C.M. Parsons (Eds.), Proceedings of the 12th annual conference of the ECS (p.111). Valencia: European Cetacean Society.

Honda, K., \& Tatsukawa, R. (1981). Ecology and bioaccumulation of Stenella coeruleoalba - heavy metal concentration in the muscle and liver tissue of Stenella coeruleoalba. In T. Fujiyama (Ed.), Studies on the levels of organochlorine compounds and heavy metals in the marine organism (pp. 2547). University of the Ryukyus.

Honda, K., \& Tatsukawa, R. (1983). Distribution of cadmium and zinc in tissues and organs, and their age-related changes in striped dolphins, Stenella coeruleoalba. Archive of Environmental Contamination and Toxicology, 12, 543-550. 
Itano, K., Kawai, S. (1981). Mercury and selenium levels in the striped dolphins in the Pacific coast of Japan. In: Fujiyama, T., ed. Studies on the levels of organochlorine compounds and heavy metals in the marine organism, University of the Ryukyus, pp.73-84.

Iverson, S.J., Frost, K.J., \& Lowry, L.F. (1997). Fatty acid signatures reveal fine scale structure of foraging distribution of harbor seals and their prey in Prince William Sound, Alaska. Marine Ecology Progress Series, 151, 255-271.

Iverson, S.J., Field, C., Bowen, W.D., \& Blanchard, W. (2004). Quantitative fatty acid signature analysis: a new method of estimating predator diets. Ecological Monographs, 74, 211-235.

IWC (International Whaling Commission), 1994. Gillnets and cetaceans. Perrin, W.F., Donovan, G.P., Barlow, J. (Eds.), Report of the International Whaling Commission, Special Issue 15.

Jepson, P.D., Bennett, P.M., Deaville, R., Allchin, C.R., Baker, J.R., Law, R.J. (2005). Relationships between polychlorinated biphenyls and health status in harbour porpoises (Phocoena phocoena) stranded in the United Kingdom. Environmental Toxicology and Chemistry, 24, 238-248.

Joiris, C.R., Holsbeek, L., Bolba, D., Gascard, C., Stanev, T., Komakhide, A., Baumgärtner, W., \& Birkun, A. (2001). Total and organic mercury in the Black Sea harbour porpoise Phocoena phocoena relicta. Marine Pollution Bulletin, 42, 905-911.

Kannan, K., Agusa, T., Perrotta, E., Thomas, N.J., \& Tanabe, S. (2006). Comparison of trace element concentrations in livers of diseased, emaciated, and non-diseased southern seaotters from the Californian coast. Chemosphere, 65, 2160-2167.

Klaassen, C.D., \& Liu, J. (1997). Role of metallothioneins in cadmium-induced hepatoxicity and nephrotoxicity. Drug Metabolism Review, 29, 79-102.

Klinowska, M. (1991). Dolphins, porpoises and whales of the world. The IUCN Red Book. Gland, Switzerland: IUCN.

Koeman, J.H., Peeters, W.H.M., Koudstaal-Hol, C.H.M., Tjioe, P.S., De Goeij, J.J.M. (1973). Mercuryselenium correlations in marine mammals. Nature, 245, 385-386.

Koschinski, S. (2002). Current knowledge on harbour porpoises (Phocoena phocoena) in the Baltic Sea. Ophelia, 55, 167-197.

Kuiken, T., \& Hartmann, M.G. (1991). Cetacean pathology: dissection techniques and tissue sampling. Proceeding of the ECS Workshop. Leiden, the Netherlands: ECS Newsletter 17.

Lahaye, V., Bustamante, P., Spitz, J., Dabin, W., Das, K., Pierce, G.J., \& Caurant F (2005). Long-term dietary segregation of common dolphins (Delphinus delphis) in the Bay of Biscay determined using cadmium as an ecological tracer. Marine Ecology Progress Series, 305, 275-285.

Lahaye, V., Bustamante, P., Dabin, W., Churlaud, C. \& Caurant, F. (submitted). Trace element concentrations in foetus-mother pairs of short-beaked common dolphins (Delphinus delphis) stranded along the French coasts. Environment International.

Law, R.J., Fileman, C.F., Hopkins, A.D., Baker, J.R., Harwood, J., Jackson, D.B., Kennedy, S., Martin, A.R., \& Morris, R.J. (1991). Concentrations of trace metals in the livers of marine mammals (seals, porpoises and dolphins) from waters around British Isles. Marine Pollution Bulletin, 22, 183-191.

Law, R.J., Jones, B.R., Baker, J.R., Kennedy, S., Milne, R., \& Morris, R.J. (1992). Trace metals in the livers of marine mammals from the Welsh coast and the Irish Sea. Marine Pollution Bulletin, 24, 296304.

Law, R.J. (1996). Metals in marine mammals. Environmental Contaminants in Wildlife: Interpreting Tissue Concentrations. In: Beyer, W.N.; Heinz; G.H.; Redmond-Norwood, A.W., eds. CRC Press, pp. 357-375. 
Learmonth, J.A. (2006). Life history and fatty acid analysis of harbour porpoises (Phocoena phocoena) from Scottish waters. PhD Thesis, University of Aberdeen.

Lockyer, C., Desportes, G., Hansen, K., Labberté, S., Siebert, S. (2003). Monitoring growth and energy utilisation of the harbour porpoise (Phocoena phocoena) in human care. In: Harbour Porpoises in the North Atlantic (eds Haug, T., Desportes, G., Víkingsson, G.A., Witting, L.), NAMMCO Scientific Publications, Volume 5, 107-120.

Mackey, E.A., Demiralp, R., Becker, P.R., Greenberg, R.R., Koster, B.J., \& Wise, S.A. (1995). Trace element concentrations in cetacean liver tissues archived in the National Marine Mammal Tissue Bank. The Science of the Total Environment, 175, 25-41.

Martoja, R., \& Berry, J.P. (1980). Identification of tiemannite as a probable product of demethylation of mercury by selenium in cetaceans. A complement to the scheme of the biological cycle of mercury. Vie Milieu, 30, 7-10.

MacDonald, C.R., \& Sprague, J.B. (1988). Cadmium in marine invertebrates and arctic cod in the Canadian Arctic. Distribution and Ecological implications. Marine Ecology Progress Series, 47, 17-30.

Møhlenberg, F., \& Jensen, A. (1980). The ecotoxicology of cadmium in fresh- and sea water and water pollution with cadmium in Denmark. Denmark: The National Agency of Environmental Protection, pp. 42.

Neve, J., \& Therond, P.P. (1991). Le selenium. In: P. Chappuis (Ed.), Les oligo-éléments en médecine et biologie. Lavoisier, Techniques et Documentation, Paris, pp. 425-457.

Nigro, M., \& Leonzio, C. (1996). Intracellular storage of mercury and selenium in different marine vertebrates. Marine Ecology Progress Series, 135, 137-143.

Palmisano, F., Cardellicchio, N., \& Zambonin, P.G. (1995). Speciation of mercury in dolphin liver: a two-stage mechanism for the demethylation accumulation process and role of selenium. Marine Environmental Research, 40, 109-121.

Paludan-Müller, P., Agger, C.T., Dietz, R., \& Kinze, C.C. (1993). Mercury, cadmium, zinc, copper and selenium in harbour porpoise (Phocoena phocoena) from West Greenland. Polar Biology, 13, 311320.

Perrin, W.F, \& Myrick, A.C. (1980). Age determination of toothed whales and sirenians. Report of the International Whaling Commission, Special Issue 3, Cambridge, UK, 229 p.

Pierce, G.J., Santos, M.B., Learmonth, J.A., Smeenk, C., Addink, M., García Hartmann, M., Boon, J.P., Zegers, B., Mets, A., Ridoux, V., Caurant, F., Bustamante, P., Lahaye, V., Guerra, A., González, A., López, A., Alonso, J.M., Rogan, E., Murphy, S., Van Canneyt, O., Dabin, W., Spitz, J., Dorémus, G., \& Meynier, L. (2004). Bioaccumulation of persistent organic pollutants in small cetaceans in European waters: transport pathways and impact on reproduction. Final Report to the European Commission's Directorate General for Research on Project EVK3-2000-00027.

Read, A.J. (1999). Harbour porpoise - Phocoena phocoena (Linnaeus, 1758). In S.H. Ridgway \& S.R. Harrison (Eds.), The second book of dolphins and porpoises, vol. 6 (pp. 323-356). San Diego: Academic Press.

Reijnders, P.J.H. (1986). Reproductive failure in common seals feeding on fish from polluted coastal waters. Nature, 324, 456-457.

Ross, P.S., de Swart, R.L., Addison, R., Loveren, H.V., Vos, J.G., \& Osterhaus, A.D.M.E. (1996). Contaminant-induced immunotoxicity in harbour seals- wildlife at risk. Toxicology, 112, 157-169. 
Santos, M.B., Pierce, G.J., Learmonth, J.A, Reid, R.J., Ross, H.M., Patterson, I.A.P., Reid, D.G., \& Beare D. (2004). Variability in the diet of harbour porpoises (Phocoena phocoena) in Scottish waters 1992-2003. Marine Mammal Science, 20, 1-27.

Scott, M.L. (1985). Nutrition of humans and selected animal species. New York: John Wiley.

Siebert, U., Joiris, C., Holsbeek, L., Benke, H., Failing, K., Frese, K., \& Petzinger, E. (1999). Potential relation between mercury concentrations and necropsy findings in cetaceans from German waters of the North and Baltic seas. Marine Pollution Bulletin, 38, 285-295.

Simmonds, M.P., Johnston, P.A., \& French, M.C. (1993). Organochlorine and mercury contamination in United Kingdom seals. The Vetenary Record, 132, 291-295.

Spitz, J., Rousseau, Y., Ridoux, V. (2006). Diet overlap between harbour porpoise and bottlenose dolphin: An argument in favour of interference competition for food? Estuarine, Coastal and Shelf Science, 70: 259-270.

Strand, J., Larsen, M.M., \& Lockyer, C. (2005). Accumulation of orgatin compounds and mercury in harbour porpoises (Phocoena phocoena) from the Danish waters and West Greenland. Science of the Total Environment, 350: 59-71.

Szefer, P., Malinga, M., Skóra, K., \& Pempkowiak, J. (1994). Heavy metals in harbour porpoises from Puck Bay in the Baltic Sea. Marine Pollution Bulletin, 28, 570-571.

Szefer, P., Zdrojewska, I., Jensen, J., Lockyer, C., Skora, K., Kuklik, I., \& Malinga, M. (2002). Intercomparison studies on distribution and coassociations of heavy metals in liver, kidney and muscle, of harbor porpoise, Phocoena phocoena, from southern Baltic and coastal waters of Denmark and Greenland. Archives of Environmental Contamination and Toxicology, 42, 508-522.

Teigen, S.W., Skaare, J.U., Bjørge, A., Degre, E., \& Sand, G. (1993). Mercury and selenium in harbor porpoise (Phocoena phocoena) in Norwegian waters. Environmental Toxicology and Chemistry, 12, 1251-1259.

Teigen, S., Andersen, R., Daae, H.L., \& Skaare, J.U. (1999). Heavy metal content in liver and kidneys of grey seals (Halichoerus grypus) in various life stages correlated with metallothioneins levels: some metal-binding characteristics of this protein. Environmental Toxicology and Chemistry, 18, 2364-2369.

Underwood, E.J. (1977). Trace elements in human and animal nutrition. New York: Academic Press, 545 p.

Wagemann, R., \& Muir, D.C.G. (1984). Concentrations of heavy metals and organochlorines in marine mammals of northern waters: overview and evaluation. Canadian Technical Report of Fisheries and Aquatic Sciences, 1279, 97 p.

Wagemann, R., Stewart, R.E.A., Lockhart, W.L., Stewart, B.E., \& Povoledo, M. (1988). Trace metals and methyl mercury: associations and transfer in harp seal (Phoca groenlandica) mothers and their pups. Marine Mammal Science, 4, 339-355.

Webb, M., \& Cain, K. (1982). Commentary: functions of metallothionein. Biochemistry and Pharmacology, 31, 137-142.

Yang, J., Kunito, T., Anan, Y., Tanabe, S., \& Miyasaki, N. (2004). Total and subcellular distribution of trace elements in the liver of a mother-fetus pair of Dall's porpoises (Phocenoides dalli). Marine Pollution Bulletin, 48, 1122-1129.

Zauke, G.P., Savinov, V.M., Ritterhoff, J., \& Savinova, T. (1999). Heavy metals in fish from the Barents Sea (summer 1994). Science of the Total Environment, 227, 161-173.

Zegers, B.N., Mets, A., Van Bommel, R., Minkenberg, C., Hamers, T., Kamstra, J.H., Pierce, G.J., \& Boon, J.P., 2005. Levels of hexabromocyclododecane in harbour porpoises and common dolphins 
from western European seas, with evidence for stereoisomer-specific biotransformation by cytochrome P450. Environmental Science and Technology, 39: 2095-2100. 


\section{Tables}

Table 1. Trace element levels (mean $\pm \mathrm{SD} ; \mu \mathrm{g} \cdot \mathrm{g}^{-1} \mathrm{~d} . \mathrm{wt}$.) in standard reference materials.

\begin{tabular}{|c|c|c|c|c|c|c|c|c|}
\hline \multirow{3}{*}{ Metals } & \multicolumn{8}{|c|}{ Standard reference materials (NRCC) } \\
\hline & \multicolumn{2}{|c|}{ TORT-2 } & \multicolumn{2}{|c|}{ DORM-2 } & \multicolumn{2}{|c|}{ DOLT-2 } & \multicolumn{2}{|c|}{ DOLT-3 } \\
\hline & $\begin{array}{l}\text { Certified } \\
\text { value }\end{array}$ & $\begin{array}{l}\text { Observed } \\
\text { value }\end{array}$ & $\begin{array}{c}\text { Certified } \\
\text { value }\end{array}$ & Observed value & $\begin{array}{l}\text { Certified } \\
\text { value }\end{array}$ & $\begin{array}{l}\text { Observed } \\
\text { value }\end{array}$ & $\begin{array}{l}\text { Certified } \\
\text { value }\end{array}$ & $\begin{array}{l}\text { Observed } \\
\text { value }\end{array}$ \\
\hline $\mathrm{Cd}$ & $26.7 \pm 0.6$ & $26.2 \pm 0.2$ & $0.046 \pm 0.008$ & $0.046 \pm 0.001$ & $20.8 \pm 0.5$ & $20.6 \pm 0.4$ & $19.4 \pm 0.6$ & $19.2 \pm 0.4$ \\
\hline $\mathrm{Cu}$ & - & - & - & - & $25.8 \pm 1.1$ & $26.2 \pm 1.0$ & $31.2 \pm 1.0$ & $30.1 \pm 0.8$ \\
\hline $\mathrm{Hg}$ & $0.27 \pm 0.06$ & $0.28 \pm 0.02$ & $4.64 \pm 0.26$ & $4.46 \pm 0.20$ & $2.14 \pm 0.28$ & $2.08 \pm 0.11$ & $3.37 \pm 0.14$ & $3.36 \pm 0.02$ \\
\hline Se & - & - & - & - & $6.06 \pm 0.49$ & $5.82 \pm 0.40$ & $7.06 \pm 0.48$ & $6.70 \pm 0.56$ \\
\hline $\mathrm{Zn}$ & - & - & - & - & $85.8 \pm 2.5$ & $86.5 \pm 2.3$ & $86.6 \pm 2.4$ & $85.1 \pm 4.3$ \\
\hline
\end{tabular}


Table 2. Trace element concentrations ( $\mu \mathrm{g} . \mathrm{g}^{-1}$ w.wt.) in 2 foetus/mother pairs of harbour porpoises, relative to mean levels $( \pm$ SD) of the overall population data $(n=102)$. CV\% is the percentage of variation, na refers to not analysed samples and y.o. to years old.

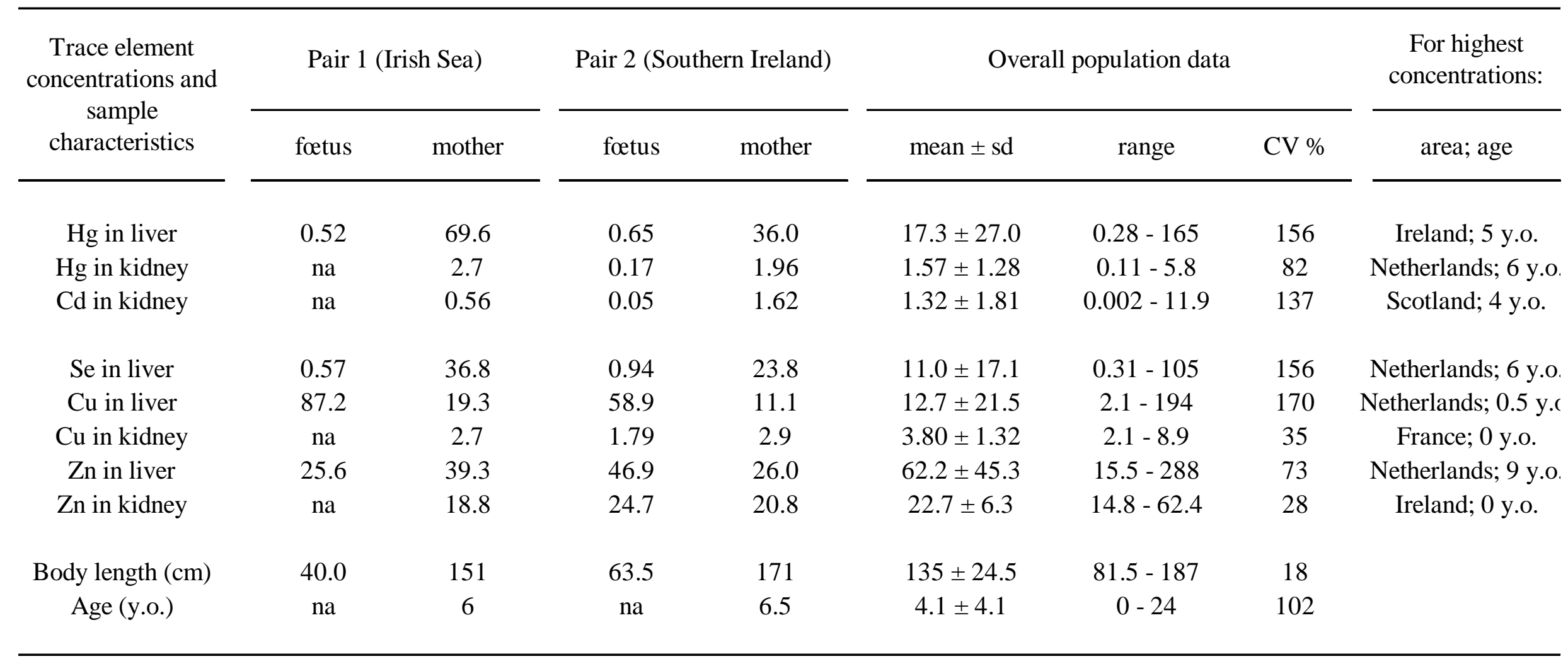



Table 3. Results of redundancy analysis (RDA). For each axis, the table shows correlations with explanatory variables, the eigenvalue as percentage of inertia $(E \%)$ and as percentage of sum of all canonical eigenvalues $(E / \Sigma E \%)$. Note: total inertia $=1.00$; sum of all canonical eigenvalues $=0.36$. $F$ statistics of conditional effects refer to the increase in explained variation due to adding extra explanatory variable.

\begin{tabular}{|c|c|c|c|c|c|c|c|c|c|}
\hline \multirow{2}{*}{ Variable } & \multirow{2}{*}{ F statistic } & \multirow{2}{*}{ P-value } & \multicolumn{5}{|c|}{ Correlation with axes } & \multirow{2}{*}{ Metals involved } & \multirow{2}{*}{ Figures } \\
\hline & & & 1 & 2 & 3 & 4 & 5 & & \\
\hline Age & 13.054 & 0.005 & 0.78 & 0.36 & 0.06 & 0.06 & 0.07 & HgL, HgK, SeL, & $2 \mathrm{a}$ \\
\hline Netherlands & 4.914 & 0.005 & 0.51 & 0.41 & 0.08 & 0.02 & 0.42 & $\mathrm{ZnL}$ & $2 \mathrm{ab}$ \\
\hline Quarter 3 & 2.499 & 0.045 & 0.03 & 0.14 & 0.51 & 0.41 & 0.21 & CuL & not shown \\
\hline POPs axis 2 & 2.458 & 0.050 & 0.04 & 0.09 & 0.14 & 0.32 & 0.14 & & \\
\hline Fatty acids axis 2 & 2.245 & 0.040 & 0.19 & 0.63 & 0.23 & 0.05 & 0.01 & $\mathrm{CdK}$ & $2 \mathrm{ac}$ \\
\hline Quarter 2 & 1.839 & 0.105 & 0.24 & 0.18 & 0.04 & 0.16 & 0.22 & & \\
\hline Quarter 1 & 2.053 & 0.040 & 0.01 & 0.02 & 0.14 & 0.33 & 0.30 & HgK & not shown \\
\hline France & 1.594 & 0.160 & 0.05 & 0.08 & 0.21 & 0.48 & 0.02 & & \\
\hline Blubber 4 & 1.546 & 0.180 & 0.07 & 0.17 & 0.33 & 0.31 & 0.15 & & \\
\hline Irlande & 1.446 & 0.215 & 0.12 & 0.13 & 0.05 & 0.00 & 0.71 & & \\
\hline Female & 1.433 & 0.200 & 0.34 & 0.15 & 0.07 & 0.09 & 0.08 & & \\
\hline Fatty acids axis 1 & 1.095 & 0.350 & 0.06 & 0.23 & 0.31 & 0.06 & 0.22 & & \\
\hline Blubber 3 & 1.080 & 0.385 & 0.17 & 0.14 & 0.08 & 0.29 & 0.01 & & \\
\hline Scotland & 1.074 & 0.340 & 0.29 & 0.36 & 0.03 & 0.30 & 0.19 & & \\
\hline POPs axis 1 & 0.833 & 0.465 & 0.12 & 0.11 & 0.19 & 0.15 & 0.12 & & \\
\hline 2002 & 0.739 & 0.600 & 0.16 & 0.06 & 0.08 & 0.37 & 0.09 & & \\
\hline 2001 & 0.841 & 0.540 & 0.14 & 0.02 & 0.24 & 0.05 & 0.31 & & \\
\hline Blubber 2 & 0.535 & 0.765 & 0.08 & 0.01 & 0.18 & 0.02 & 0.13 & & \\
\hline Blubber 1 & 1.419 & 0.200 & 0.35 & 0.14 & 0.01 & 0.13 & 0.37 & & \\
\hline \multirow[t]{3}{*}{2003} & 0.498 & 0.800 & 0.14 & 0.01 & 0.10 & 0.21 & 0.05 & & \\
\hline & & $\mathrm{E} \%$ & 17.77 & 5.66 & 4.64 & 3.06 & 2.62 & \multirow{2}{*}{\multicolumn{2}{|c|}{$\begin{array}{c}\text { Cumulative } \mathrm{E} \%=33.7 \\
\text { Cumulative } \mathrm{E} / \Sigma \mathrm{E} \%=93.9\end{array}$}} \\
\hline & & $\mathrm{E} / \Sigma \mathrm{E} \%$ & 49.46 & 15.75 & 12.90 & 8.51 & 7.30 & & \\
\hline
\end{tabular}


Table 4. Spearman rank correlation matrix between trace elements in the liver and the kidneys of harbour porpoises stranded along the European coast. Bold characters refer to significant correlations $(\alpha=0.05)$.

\begin{tabular}{|c|c|c|c|c|c|c|c|c|}
\hline & \multicolumn{4}{|c|}{ Liver } & \multicolumn{4}{|c|}{ Kidney } \\
\hline & $\mathrm{Hg}$ & $\mathrm{Se}$ & $\mathrm{Cu}$ & $\mathrm{Zn}$ & $\mathrm{Hg}$ & $\mathrm{Cd}$ & $\mathrm{Cu}$ & $\mathrm{Zn}$ \\
\hline \multicolumn{9}{|l|}{ Liver } \\
\hline $\mathrm{Hg}$ & +1 & & & & & & & \\
\hline $\mathrm{Se}$ & +0.909 & +1 & & & & & & \\
\hline $\mathrm{Cu}$ & +0.003 & +0.036 & 1 & & & & & \\
\hline $\mathrm{Zn}$ & +0.068 & -0.002 & +0.004 & +1 & & & & \\
\hline \multicolumn{9}{|c|}{ Kidney } \\
\hline $\mathrm{Hg}$ & +0.889 & +0.855 & -0.055 & +0.019 & +1 & & & \\
\hline $\mathrm{Cd}$ & +0.529 & +0.544 & -0.020 & +0.086 & +0.350 & +1 & & \\
\hline $\mathrm{Cu}$ & -0.219 & -0.299 & +0.290 & +0.160 & -0.252 & +0.030 & +1 & \\
\hline $\mathrm{Zn}$ & -0.062 & -0.115 & +0.065 & +0.399 & -0.112 & +0.177 & +0.498 & +1 \\
\hline
\end{tabular}


Table 5. Hepatic $\mathrm{Hg}$ and renal Cd levels ( $\mu g \cdot \mathrm{g}^{-1}$ w.wt.) in harbour porpoises (literature data). Key: * refers to geometric mean; ${ }^{\star}$ d. wt. converted in w.wt. on the basis of the d.wt. : w.wt. ratio obtained durina this studv. LD is limit of detection.

\section{Geographical location}

Sub-area

Greenland
West*
West

South West

\section{Northwestern Atlantic}

Canada (Bay of Fundy)

US

\section{North Sea}

Iceland**

Norway

Norway**

Scotland (East)

Scotland (East)

Denmark

Denmark**

Denmark (Inner waters)

Germany**

Belgium and France

Netherlands and France

\section{Baltic Sea}

Poland

Poland

Germany**

\section{Celtic shelf}

Scotland (North West)

Ireland**

Ireland (South)

Ireland and Scotland (Irish Sea)

Ireland and Wales (Irish Sea)

England and Wales

France (Channel)**

France (Channel)

Bay of Biscay

France

Spain (Galicia)

Black Sea

Black Sea

Black Sea**
Reference

Palludan-Müller et al., 1993

Strand et al., 2005

Szefer et al., 2002

Gaskin et al., 1979

Mackey et al., 1995

Das et al., 2004a

Teigen et al. 1993

Das et al., 2004a

Falconer et al., 1983

This study

Strand et al., 2005

Das et al., 2004a

Strand et al., 2005

Das et al., 2004a

Das et al., 2004a This study

Szefer et al., 1994

Ciesielski et al., 2006

Das et al., 2004a

\section{This study}

Das et al., 2003

This study

This study

Law et al., 1992

Bennett et al., 2001

(infectious disease)

(physical trauma)

Das et al., 2003

This study

This study

This study

Joiris et al., 2001

Das et al., 2004b
Hepatic Hg

\begin{tabular}{ccc}
\hline $\mathrm{n}$ & Mean \pm sd & Range \\
\hline 44 & 4,2 & $0.48-20.7$ \\
2 & 6,6 & $6.9-6.3$ \\
& na & na
\end{tabular}

$0.5-112$

68

12

$9.9 \pm 15.2$

$0.56-38.6$

11

\section{$4.6 \pm 4.1$}

$2.9 \pm 3.2$

$4.1 \pm 2.9$

na

$8.7 \pm 10.1$

$8.5 \pm 10.2$

$6.4 \pm 10.4$

$6.4 \pm 20$

$4.1 \pm 5.2$

$6.7 \pm 19.1$

$25.8 \pm 33.6$

$0.41-12.8$

$0.26-9.9$

$0.29-9.3$

$0.28-15.9$

$0.38-31$

$0.42-32.8$

$0.29-42.6$

$0.22-92$

$0.29-16.2$

$0.17-99.8$

$0.88-139.4$

na

na

$6.6 \pm 16.9$

$1.31 \pm 1.04$

$0.46-65.1$

$0.26-3.4$

$1.2-26.0$

$12.4 \pm 11.8$

$7.0 \pm 12.2$

$1.19-28.7$

$16.1 \pm 20.8$

$0.28-54.9$

$30.0 \pm 48.8$

$0.81-165.0$

$0.6-190$

$37 \quad 20.0 \pm 5.5$

$49 \quad 12.3 \pm 3.4$

na

na

$2.6 \pm 3.2$

$10.7 \pm 14.3$

$0.87-7.5$

$0.80-40.0$

$0.99-65.5$

$0.96-1.58$

$0.14-9.9$

1,9

$\begin{array}{lll}41 & 2.4 \pm 2.8 & 0.17-8.8\end{array}$

$\begin{array}{lll}41 & 2.4 \pm 2.8 & 0.17-8.8\end{array}$

Renal Cd

\begin{tabular}{ccc}
\hline $\mathrm{n}$ & Mean $\pm \mathrm{sd}$ & Range \\
\hline 26 & 13,2 & $0.11-72.5$ \\
& na & na \\
42 & 55,3 & $0.32-210$
\end{tabular}

na

na

na

na

$\begin{array}{ccc}11 & 4.4 \pm 3.9 & <\text { LD }-54.7 \\ & \text { na } & \text { na } \\ 20 & 1.38 \pm 1.04 & <\text { LD }-3.7 \\ 23 & \text { na } & 0.17-7.42 \\ 19 & 2.30 \pm 2.56 & <\text { LD }-11.9 \\ & \text { na } & \text { na } \\ 15 & 0.25 \pm 0.23 & 0.023-0.81 \\ & \text { na } & \text { na } \\ 12 & 0.92 \pm 2.1 & <\text { LD }-7.59 \\ 48 & 0.71 \pm 0.71 & <\text { LD }-2.8 \\ 22 & 0.84 \pm 0.85 & 0.04-3.52\end{array}$

$4 \quad 1.41 \pm 1.05$

$0.21-2.7$

na

$<\mathrm{LD}-1.15$

$0.25 \pm 0.35$

$2.3-10.4$

6,4

$0.90 \pm 0.78$

$0.09-2.3$

$0.04-3.19$

$1.03-0.84$

$<$ LD - 1.66

na

na

na

na

na

$0.35 \pm 0.62$

$<$ LD - 1.29

$0.01-1.64$

$42 \quad 1.33 \pm 1.08$

na

$<$ LD - 3.5 


\section{Figures}

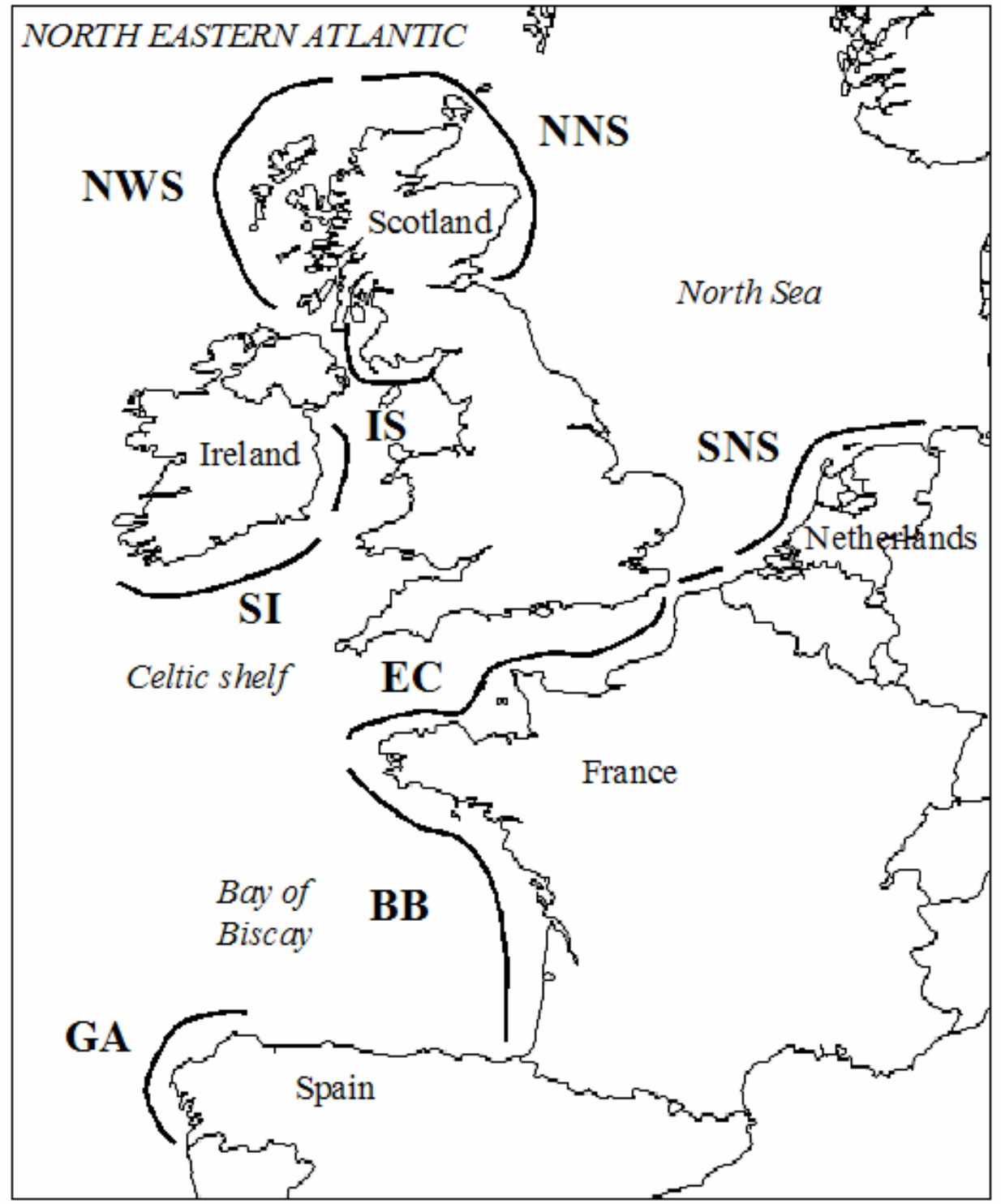

Figure 1. Map of the sampling area from which stranded harbour porpoises were collected: NNS = Northern North Sea (Scottish east coast); SNS = Southern North Sea (Dutch/French coast, north of Calais); NWS = Northwest coast of Scotland; IS = Irish Sea (Scottish west coast south of Campbeltown and Irish east coast); SI = Southern Ireland (Celtic Sea); EC = Channel (French north coast, south of Calais); $\mathrm{BB}=$ Bay of Biscay (French west coast); GA = Galician north and west coasts. 

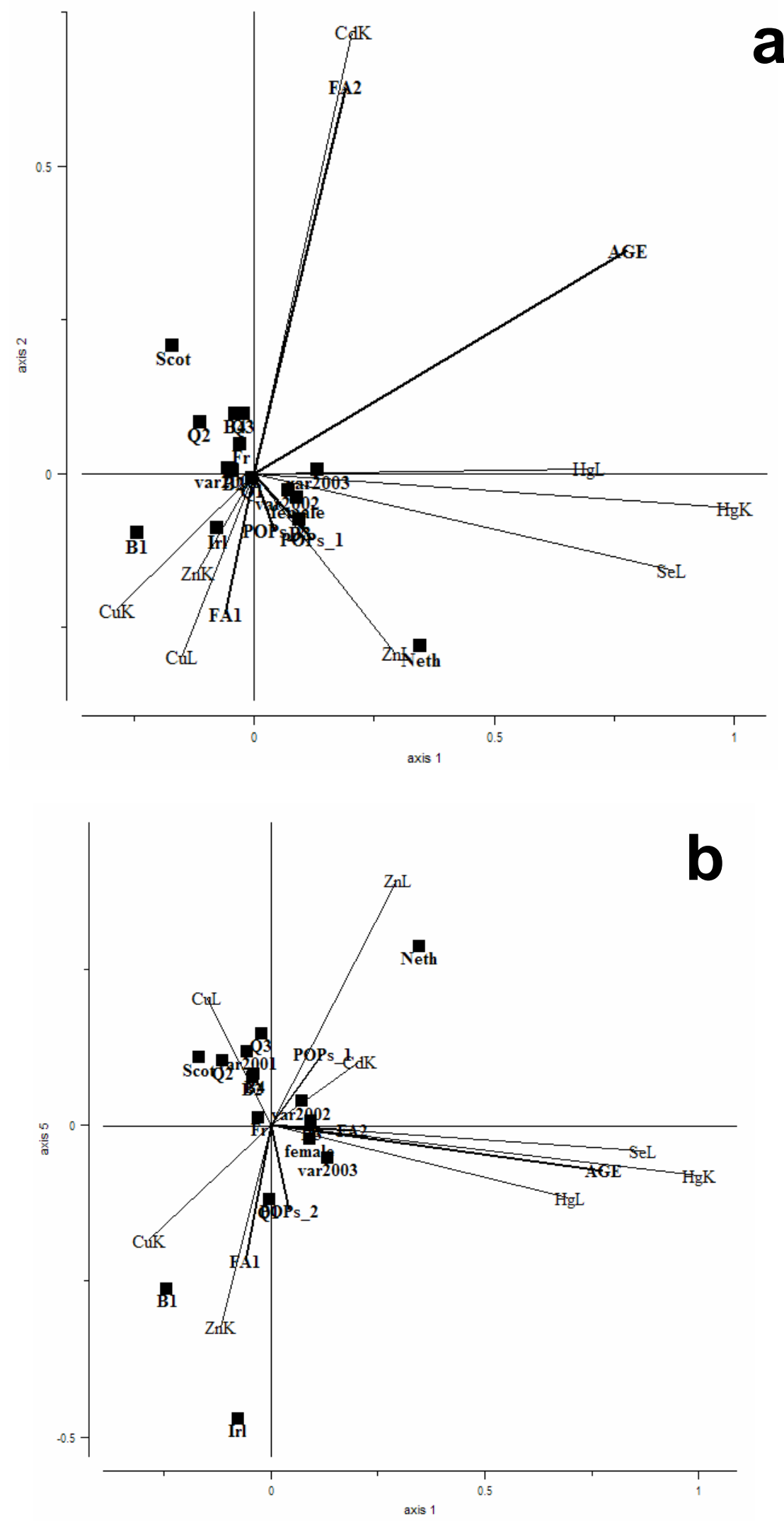


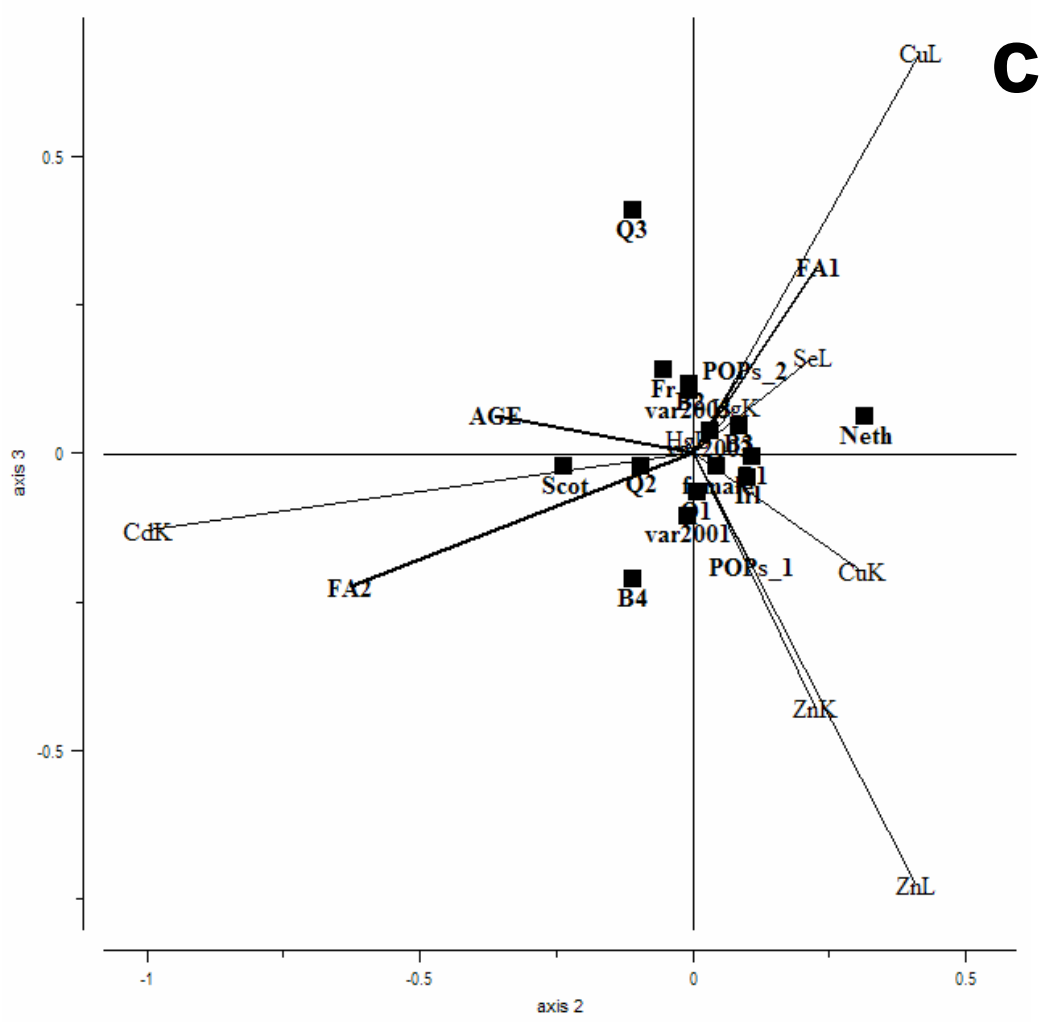

Figure 2. RDA biplot on trace element data: a) axes 1-2, b) axes 1-5, c) axes 2-3. With: Cd, Cu, Hg, Se, Zn "L or K" referring to "in Liver or in Kidneys"; "B1 to B5", to Blubber classes; "Q1 to Q4", to Quarters; "FA 1 and 2", the first two axes of the PCA carried out on Fatty Acids; "POP1 and 2", the first two axes of the PCA carried out on POPs; "Neth", Netherlands; "Scot", Scotland; "Irl”, Ireland; and "Fr", France. 


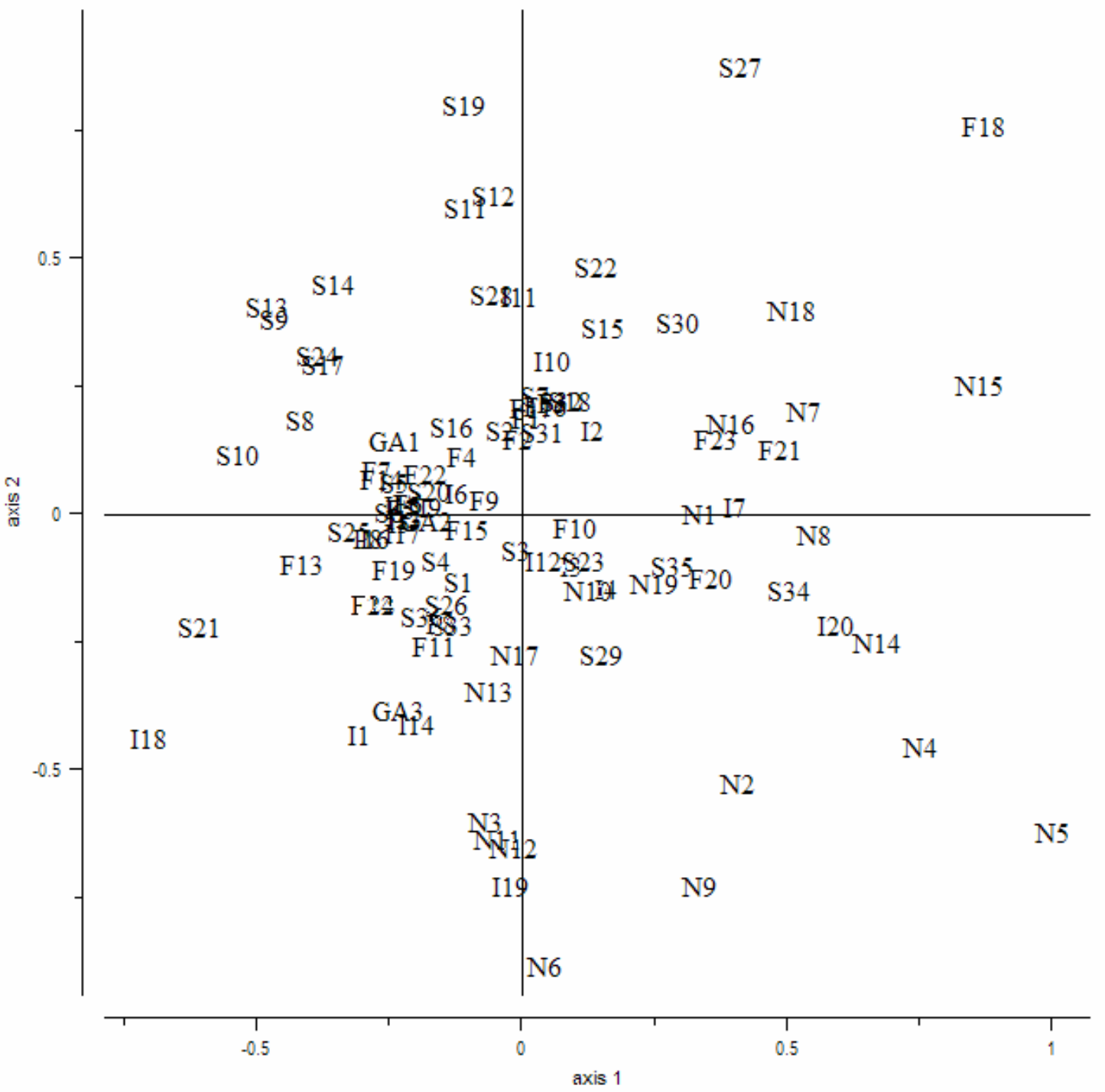

Fig.3. Individual scores for harbour porpoises from European waters plotted on the first two axes of the RDA. With: $F=$ France; $G A=$ Galicia; I = Ireland; $N=$ Netherlands; $\mathrm{S}=$ Scotland. 


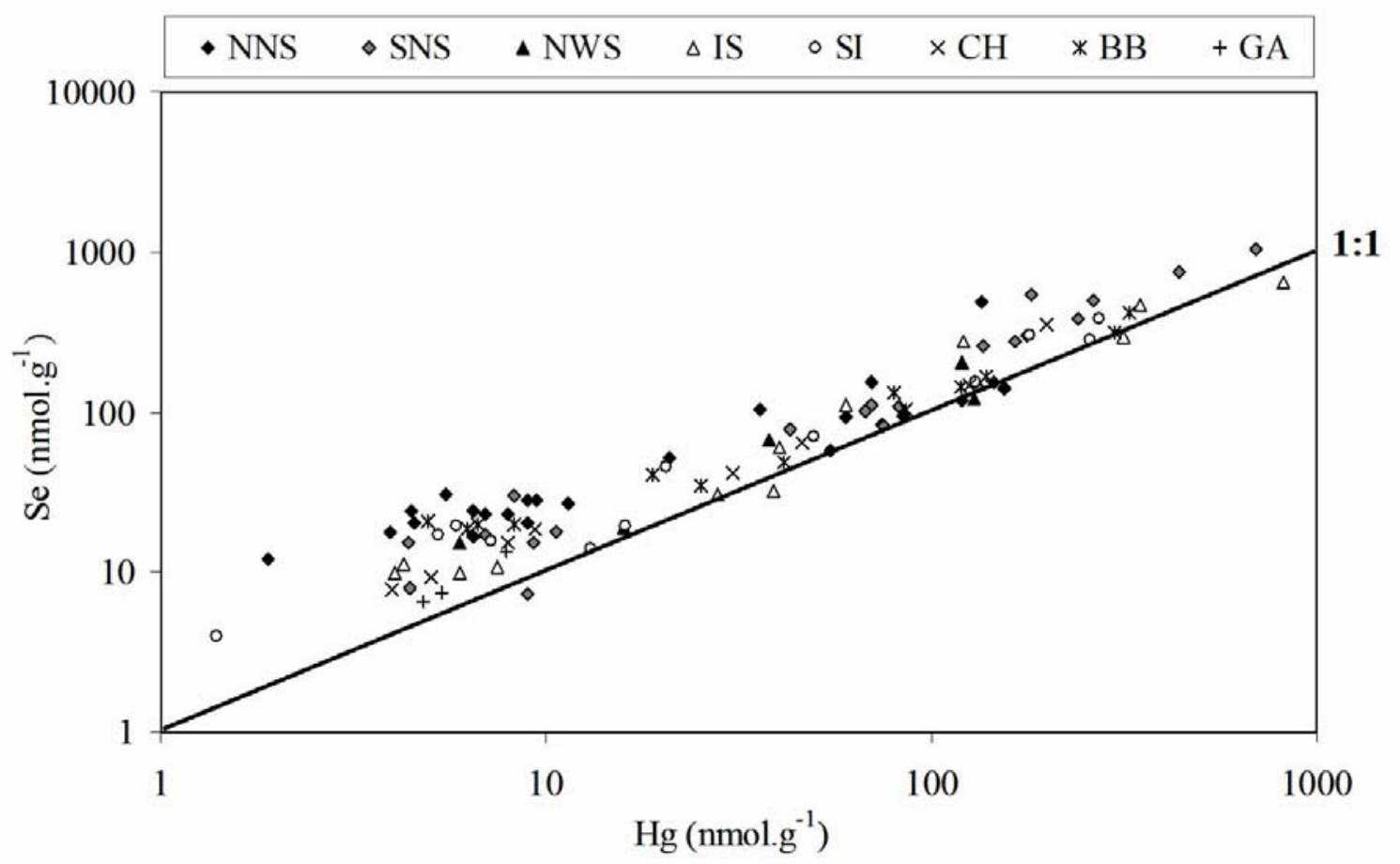

Fig.4. Molar Se and molar $\mathrm{Hg}$ concentrations in liver tissue of harbour porpoises stranded along the European coast: NNS = Northern North Sea; SNS = Southern North Sea; NWS = Northwest coast of Scotland; IS = Irish Sea; SI = Southern Ireland; $\mathrm{CH}=$ Channel; $\mathrm{BB}=$ Bay of Biscay; $\mathrm{GA}=$ Galicia. 